\title{
Arterial stiffness and ankle brachial index in patients with rheumatoid arthritis and inflammatory bowel disease
}

\author{
Kadir Ozturk
}

\section{To the Editor;}

We read the article "Comparison of inflammation, arterial stiffness and traditional cardiovascular risk factors between rheumatoid arthritis and inflammatory bowel disease" by Fan et al. [1] with great interest. In this verywell designed study, authors found that pulse wave velocity (PWV) levels were similar between rheumatoid arthritis (RA), inflammatory bowel disease (IBD) and control groups. In addition, they also showed that ankle brachial index (ABI) levels were higher in controls than IBD, but not RA. They concluded that traditional risk factors, but not inflammatory markers, are major parameters asscociated with arterial stiffness. These findings provide new information about the asscociation between inflammatory diseases and atherosclerosis.

In this study, although RA patients have higher Framingham risk score and number of hypertensive patients, there was no significant difference between RA and control groups in PWV and ABI levels. Arterial stiffness has been known as an independent predictor cardiovascular mortality and is increased in rheumathologic diseases despite a low risk for cardiovascular disease according to Framingham score [2]. Moreover, in IBD patients, ABI levels were significantly decreased when compared to control subjects, but PWV levels were not correlated with ABI. Whereas a negative correlation between PWV and ABI was demonstrated in individuals without organic heart disease [3].

We suggest some possible explanations for the lack of increased PWV and decreased ABI in patients with RA and IBD than controls. In present study, authors did not examine renal function tests and hemoglobin levels. We know that patients with chronic renal failure and anemia have increased risk for cardiovascular events and peripheral artery disease $[4,5]$. Moreover, they did not examine

Correspondence: kadirozturk3041@gmail.com

Department of Gastroenterology, Gulhane School of Medicine, Ankara, Turkey 
Table 1 Laboratory results of study population

\begin{tabular}{lcc}
\hline & RA $(n=43)$ & IBD $(n=42)$ \\
\hline Urea, $\mathrm{mg} / \mathrm{dL}$ & $5.6 \pm 2.2$ & $5.8 \pm 2.5$ \\
Creatinine, $\mu \mathrm{moL} / \mathrm{L}$ & $68.7 \pm 16.2$ & $79.9 \pm 38.1$ \\
Hemoglobin, $\mathrm{g} / \mathrm{L}$ & $134.1 \pm 18.4$ & $137.4 \pm 16.5$ \\
\hline
\end{tabular}

and high systolic blood pressure were major determinants, which is concistent with our findings. ABI was not corrrelated with vascular parameters in either RA or IBD. Although negative correlation between PWV and ABI have been demonstrated in individuals without organic heart disease [3], we did not observe such inverse correlation in our study.

Finally, we appreciate and agree with the comment that patients with chronic renal failure and anaemia have increased risk for cardiovascular events and peripheral artery disease [4, 5]. As suggested we have examined data on renal function (urea, creatinine) and haemoglobin, which are all within the normal range (Table 1 ).

\section{Competing interests}

The authors declare they have no competing interests.

Received: 9 November 2014 Accepted: 5 January 2016

Published online: 08 January 2016

\section{References}

1. Fan F, Galvin A, Fang L, White DA, Moore XL, Sparrow M, et al. Comparison of inflammation, arterial stiffness and traditional cardiovascular risk factors between rheumatoid arthritis and inflammatory bowel disease. J Inflamm (Lond). 2014;11:29.

2. Sacre K, Escoubet B, Pasquet B, Chauveheid MP, Zennaro MC, Tubach F, et al. Increased arterial stiffness in systemic lupus erythematosus (SLE) patients at low risk for cardiovascular disease: a cross-sectional controlled study. PLoS One. 2014;9, e94511.

3. Su HM, Lee KT, Chu CS, Lee MY, Lin TH, Voon WC, et al. Effects of heart rate on brachial-ankle pulse wave velocity and ankle-brachial pressure index in patients without significant organic heart disease. Angiology. 2007;58:67-74.

4. Ford ML, Tomlinson LA, Chapman TP, Rajkumar C, Holt SG. Aortic stiffness is independently associated with rate of renal function decline in chronic kidney disease stages 3 and 4. Hypertension. 2010:55:1110-5.

5. Foster MC, Ghuman N, Hwang SJ, Murabito JM, Fox CS. Low ankle-brachial index and the development of rapid estimated GFR decline and CKD. Am J Kidney Dis. 2013;61:204-10.

6. Cypiene A, Laucevicius A, Venalis A, Ryliskyte L, Dadoniene J, Petrulioniene $Z$, et al. Non-invasive assessment of arterial stiffness indices by applanation tonometry and pulse wave analysis in patients with rheumatoid arthritis treated with TNF-alpha blocker remicade (infliximab). Proc West Pharmaco Soc. 2007;50:119-22.

7. Scolnik M, Saucedo C, Navarta OD, Ferreyra GL, Lancioni E, Varela GF, et al. Lipid alterations and measurement of arterial stiffness in rheumatoid arthritis. Arthritis Rheum. 2012;64 Suppl 10:1268.

8. Sliem H, Nasr G. Change of the aortic elasticity in rheumatoid arthritis: relationship to associated cardiovascular risk factors. Journal of cardiovascular disease research. 2010;1(3):110-5.

9. Zanoli L, Cannavo M, Rastelli S, Di Pino L, Monte I, Di Gangi M, et al. Arterial stiffness is increased in patients with inflammatory bowel disease. J Hypertens. 2012;30(9):1775-81.

10. Theocharidou E, Mavroudi M, Soufleris K, Griva T, Giouleme O, Athyros VG, et al. Aortic stiffness in patients with inflammatory bowel diseases. Hellenic J of Atherosclerosis. 2013;4(3):200-7

11. Maki-Petaja KM, Elkhawad M, Cheriyan J, Joshi FR, Ostor AJ, Hall FC, et al. Antitumor necrosis factor-alpha therapy reduces aortic inflammation and stiffness in patients with rheumatoid arthritis. Circulation. 2012;126(21):2473-80.
12. Protogerou AD, Zampeli E, Fragiadaki K, Stamatelopoulos K, Papamichael C, Sfikakis PP. A pilot study of endothelial dysfunction and aortic stiffness after interleukin-6 receptor inhibition in rheumatoid arthritis. Atherosclerosis. 2011;219(2):734-6.

13. Tam LS, Shang Q, Li EK, Wang S, Li RJ, Lee KL, et al. Infliximab is associated with improvement in arterial stiffness in patients with early rheumatoid arthritis - a randomized trial. The Journal of rheumatology. 2012;39(12): 2267-75.

14. Lee JH, Cho Kl, Kim SM. Carotid arterial stiffness in patients with rheumatoid arthritis assessed by speckle tracking strain imaging: its association with carotid atherosclerosis. Clin Exp Rheumatol. 2012;30(5):720-8.

15. Kim YS, Sung YK, Choi CB, Uhm WS, Kim TH, Shin JH, et al. The major determinants of arterial stiffness in Korean patients with rheumatoid arthritis are age and systolic blood pressure, not disease-related factors. Rheumatol Int. 2012;32(11):3455-61.
Submit your next manuscript to BioMed Central and we will help you at every step:

- We accept pre-submission inquiries

- Our selector tool helps you to find the most relevant journal

- We provide round the clock customer support

- Convenient online submission

- Thorough peer review

- Inclusion in PubMed and all major indexing services

- Maximum visibility for your research

Submit your manuscript at www.biomedcentral.com/submit 